\title{
REVIEWING AL-QAEDA'S INFILTRATION IN INDONESIA: A HISTORICAL REFLECTION
}

\author{
HERDI SAHRASAD, ${ }^{1}$ YANUARDI SYUKUR ${ }^{2}$ \\ DEDY TABRANI, ${ }^{3}$ AND AL CHAIDAR ${ }^{4}$ \\ ${ }^{1}$ Universitas Paramadina, Jakarta \\ ${ }^{2}$ Universitas Khairun, Ternate \\ ${ }^{3}$ Sekolah Tinggi Ilmu Kepolisian, Jakarta \\ ${ }^{4}$ Universitas Malikussaleh, Aceh Utara
}

\section{Abstract}

Al-Qaeda's infiltration into the Southeast Asian region is inseparable from the existence of Jamaah Islamiyah (JI). Some Jamaah Islamiyah cadres are veterans of the Afghanistan War. Historically Al-Qaeda under the leadership of Osama Bin Laden has trained the military skills of Jamaah Islamiyah cadres to help the Afghan jihadists fight Soviet communism until the Soviets defeated and left Afghanistan. Then Al-Qaeda succeeded in entering Indonesia through the Jamaah Islamiyah network and its cells in Southeast Asia by mobilizing key actors and radical actions. In Indonesia, Jamaah Islamiyah with the support of Al-Qaeda succeeded in carrying out a series of bomb attacks including Bali Bomb (2002), Kuningan Bomb (2004), JW Marriot and Ritz-Carlton Bomb Jakarta (2009). The strategy of the Al-Qaeda movement in Indonesia does not appear openly by forming an underground organization (clandestine). Its existence exists but in the form of a Formless Organization (OTB) for the security of its organization. Their infiltration through these networks has succeeded in bringing in their radical ideology and movements in Indonesia in particular and in

* Coordinating author: Jalan Gatot Subroto No.Kav. 97, RT.4/RW.4, Mampang Prapatan, Kec. Mampang Prapatan, Kota Jakarta Selatan, Daerah Khusus Ibukota Jakarta 12790. Email: sahrasad@yahoo.com.

ISSN 0852-7172 (p) 2461-064X (e) 
SAHRASAD, SYUKUR, TABRANI, AND CHAIDAR

the Southeast Asian region in general.

Infiltrasi Al-Qaeda ke kawasan Asia Tenggara tidak terlepas dari keberadaan Jamaah Islamiyah (JI). Sejumlah kader Jamaah Islamiyah adalah veteran Perang Afghanistan. Secara historis Al-Qaeda di bawah pimpinan Osama Bin Laden telah melatih keterampilan militer para kader Jamaah Islamiyah guna membantu kaum mujahiddin Afghanistan melawan komunisme Uni Soviet hingga Soviet kalah dan meninggakan Afghanistan. Selanjutnya Al-Qaeda berhasil masuk ke Indonesia melalui jaringan Jamaah Islamiyah dan sel-selnya di Asia Tenggara dengan mengerahkan aktor-aktor kunci dan tindakan-tindakan yang radikal. Di Indonesia, Jamaah Islamiyah dengan dukungan Al-Qaeda berhasil menjalankan serangkaian serangan bom diantaranya: Bom Bali (2002), Bom Kuningan (2004), Bom Marriot dan Ritz-Carlton Jakarta (2009). Adapun strategi gerakan Al-Qaeda di Indonesia tidak menampakkan diri secara terbuka dengan membentuk organisasi bawah tanah (clandestine). Eksistensinya ada, namun berbentuk Organisasi Tanpa Bentuk (OTB) demi keamanan organisasinya. Infiltrasi mereka melalui jaringan-jaringan ini telah berhasil membawa masuk ideologi dan gerakan radikal mereka di Indonesia khususnya dan di wilayah Asia Tenggara secara umum.

KeywordS: Al-Qaeda; Jamaah Islamiyah; terrorism; Indonesia.

\section{Introduction}

Al-Qaeda is not only active in Afghanistan but also spreads to other places, including Indonesia. This movement is difficult to track structurally, but anti-American / anti-Western terror acts cannot be separated from Al-Qaeda interference. In 1998, Bin Laden called for a fatwa on all Muslims to kill Americans. Laden said, "We don't distinguish between military and civilian". All are targets in this fatwa (Kean 2004, 64).

In his statement, Osama said that the actions carried out 


\section{REVIEWING AL-QAEDA'S INFILTRATION}

with acts of terrorism were in the name of religion and God's command. Therefore, the study of terrorism conducted by Hoffman (2006) states that almost all radical Islamists in their acts of terror always claim/act in the name of religion and claim the command of God.

This paper explains why the Al-Qaeda movement is interested in spreading its ideas and actions to Indonesia. Based on the Afghanistan War and the military training carried out by "Afghan Arab" fighters in camps near Peshawar and Afghanistan, Al-Qaeda formed an ideological unit for the mujahideen. Unity of view in seeing the world will lead to the unity of the movement, although geographically separated.

Abegebriel said:

"In a camp near Peshawar and also a camp in Afghanistan, these mujahideen met each other for the first time, studying, training together, joint training exercises, and also they told each other the conditions of their respective countries. The first advantage they get is an exchange of ideas and lengthy discussion about the Islamic movements that have sprung up in their countries and from all regions with all of their ideas including the strict enforcement of Islamic law. From here they have an ideological network of international scale and enthusiasm that leads to a longterm agenda where someday after they return they will be practiced and applied in their respective countries. This camp has become like the Virtual Universities for Future Islamic Radicalism” (Dreyfuss 2007).

The spread of the Al-Qaeda movement is a necessity. At present, the development of the world is so fast. Easy transportation, supported by information in cyberspace, and telecommunications make their movement spread so fast, moreover, this movement bases its footing on religious doctrine. The Al-Qaeda movement, which until now has consistently been a direct op- 
ponent of America, has not inspired other activists in the same league to fight America and its allies. The al-Qaeda movement which spread to many places - more than 50 countries - is due to several reasons: First, American politics; Second, the vision of unification of Muslims; Third, the climate of freedom after the 1998 Reformation.

\section{American, Afghan and Middle Eastern politics}

After World War II, world polarization was divided into Western and Eastern blocs. West is represented by America (Capitalist) and East by the Soviet Union (Communist). Competition between the two countries takes place in various fields: military coalition, ideology, psychology, military, industry, technology, nuclear race, and weaponry. To win its hegemony in the Middle East, America helped the mujahideen drive out Communist troops from Afghanistan.

The Afghanistan War occurred because it was triggered by the Soviet Union's desire to maintain a "satellite regime", and that was the cause of the Cold War. For America, the Soviet Union's attack on Afghanistan was a "challenge" to the Reagents government which propagated a military movement against the communist regime and was seen as an "insult" to America (Huntington 2007, 455-56). The rivalry between these two giant countries contributed greatly to political dynamics and conflict in the Middle East region (Edwards and Hinchcliffe 2004, 36)

After the collapse of the Soviet Union and the Communist countries in Europe, America achieved the only superpower in the world, which could theoretically do anything it wanted. He advocated democratization in the Middle East, but his foreign policy was of a double standard, especially in the case of Israel (Zainuddin 2004, 237-38). Previously, the East region was British territory. Egypt, Iraq, and Iran-although relatively independent-are de facto under British rule. Palestine and Transjordan 


\section{REVIEWING AL-QAEDA'S INFILTRATION}

are officially a British mandate. The countries that later became Kuwait and the other "shaikhdom" (kingdoms / "shaikhs") were the British colonies, as were India and Pakistan. However, Britain's power slowly weakened and was replaced by a rapidly growing American involvement. First of all, it starts with Saudi Arabia which is the entry point for US presence in the region. US relations with Saudi Arabia and the Middle East were driven by a desire for oil and the logic of the siege of the Cold War.

US entry into the region began in 1945, aboard a ship anchored at the Great Bitter Lake above the Suez Canal. There, in February, on his way back to Washington from Yalta, Franklin Delano Roosevelt met King Abdul Aziz bin Saud. The first meeting between an American president and the Saudi king was a stake for the continuation of relations between the two countries.

In 1933, there was a decisive event in the Middle East, namely the signing of a US oil concession in Saudi Arabia that developed into the world oil superpower, the Arabian-American Oil Company (Aramco). A year after the agreement, Roosevelt said that the defense of Saudi Arabia was very important for the defense of the United States.

According to Robert Dreyfuss, the efforts of US President Roosevelt to partner with Saudi Arabia have many goals. Oil is one of them. Dreyfuss (2007, 63-68) writes that a clear goal that is, Saudi Arabia oil is a very valuable resource. FDR's statement in 1943, that America would defend Saudi Arabia, was then reaffirmed by every American president. The most prominent statements are found in the Eisenhower Doctrine of 1957 and the Carter Doctrine of 1980. In 1940, the United States sent its first military mission to the Saudis. Then in 1945 the United States and the Saudis signed an agreement on military cooperation to build a US Air Force base in Dhahran in the Persian Gulf region - a facility that would later become an American mili- 
tary base until the 1960s. The agreement was then followed by an agreement in 1949 in the form of granting permission to a US survey team to protect the entire Arabian peninsula. The team recommended the formation of an army and air force consisting of 43,000 people equipped with weapons by the US. In 1951, an agreement reached between the two countries was to set up a permanent US military training mission. In 1945 when British and American architects began to think of ways to counter Soviet defenses, Islam was included as a factor. During the Truman and Eisenhower administrations, the United States still made a series of efforts to mobilize political Islam into the Cold War and to use Islam as a weapon against Soviet influence.

Among America's efforts to consider is the "Red Pigs" program. As part of the American approach to political Islam in the 1950s, the program seeks to win propaganda points by emphasizing that the US is a godly nation and the Soviet Union is a country that breaks religion. That way, the Muslims as a nation that is equally religious with the US, need to help each other against the "godless" people.

In 1979, the idea of overthrowing the Soviets using Islamic "hands" began to be put into practice. The United States, Pakistan, and Saudi Arabia officially launched a fundamentalist Islamic jihad that threatened the government in Kabul, provoked the Soviet Union to invade Afghanistan and sparked a civil war for ten years. Zbigniew Brzezinski, national security advisor President Carter said that CIA assistance for the mujahideen had begun on July 3, 1979. At that time President Carter signed the first instructions for secret assistance for opponents of the pro-Soviet regime in Kabul. This assistance, according to Brzezinski, would "trigger Soviet military intervention". Brzezinski wrote in 1979 to President Carter, "now we can give the USSR its own Vietnam war" (Dreyfuss 2007, 339-40; Wright 2007, 114). 


\section{REVIEWING AL-QAEDA'S INFILTRATION}

After the defeat of the Soviet Union in Afghanistan, the jihad carried out by the Mujahideen did not stop there. From the experience of jihad, it eventually became a means of bringing closer between "Afghan Arab" fighters from different countries. Osama bin Laden, later formed Al-Qaeda who used the resources of Afghan alumni to launch his actions against America.

What made Al-Qaeda launch attacks on America was because of its hegemonic and aggressive foreign policy. During Bill Clinton, there was a signing of a peace agreement between Jordan and Israel that took place on October 26, 1994. From one side, the peace could be considered a "historic event" because it officially ended the hostilities that had lasted for about half a century. However, the people who benefit most from the peace agreement are the United States and its ally Israel.

For the US, that event further strengthened the dominance and hegemony of US politics in the Middle East and the Arab world. At that time it could be said that no Arab country dared to oppose the US. The countries of Sudan, Libya, and Iraq which are included "vocal", are inseparable from the extraordinary pressure from the US On behalf of the UN, for example, the US succeeded in isolating Iraq, Iran and silencing Libya. Meanwhile, Sudan, which since 1993 (when Bin Laden was in Sudan), was included as a terrorism supporting countries only because of applying Islamic law, continued to face famine and civil war as long as Islamic law was still applied by the government of Omas Bashir (Sihbudi 2007, 132-33).

Besides, US foreign policy which prioritizes "Israel First" doctrine, is the reason for Al-Qaeda's hatred. Israel is a racist state that established a Jewish state on the blood of Palestinians. Until now, America has ceaselessly allocated its foreign aid to Israel. With these funds, it will certainly increase the ability of Israel in many ways, including to protect the country from the onslaught of Palestinian fighters. 
Since World War II, according to 2003 data, US has donated more than 140 billion dollars to Israel. Every year, Israel receives around $\$ 3$ billion in aid, which is equivalent to one-fifth of the total US foreign aid or $\$ 500$ per year to every Israeli citizen. Israel is the only recipient of aid that does not need to report for what the funds are used (Mearsheimer and Walt 2007, 16).

The 140 billion dollar figure mentioned above only refers to assistance to Israel. There are many other components of funds that have been spent by the US for Israel. For example, due to the 1973 Arab-Israeli war, in order to save Israel, the US established diplomacy with the enemies of Israel, Egypt, and Jordan; they were given financial assistance in return for their willingness to establish peace with Israel. Not to mention the funds that must be spent by the US to build military bases in the Middle East which all aim to protect Israel (Sulaeman 2010).

Thomas R. Stauffer, lecturer in Energy Economics and Middle East at Harvard University, calculates the component of funds that the US has spent so far, both directly and indirectly, due to its support for Israel, namely: 3 trillion dollars. Sulaeman (2010) writes that in 2007, Deputy Secretary of State Bush President Nicholas Burns signed an MoU between the US-Israel that contained an agreement that the US would provide military assistance of 3 billion dollars annually within 10 years. That is, there is an increase in aid by $25 \%$. When signing the agreement at the Israeli Foreign Ministry office, Burns said, "The only way to achieve peace is to show Iran and Syria that the US will always be a major factor instability in the region. We will always defend our friends ".

To see the foreign policy, one factor that needs attention is image or assumption. According to Coplin, the complexity and uncertainty of information about the international environment make decision-makers tend to build images or assumptions about international conditions. Coplin writes that in many 


\section{REVIEWING AL-QAEDA'S INFILTRATION}

ways, assumptions are simplified to dogma; because of the large bets involved, foreign policy decision-makers are rarely able to avoid the insecurities that may arise from the review of existing images. Because foreign policy decision-makers depend on their image in directing their behavior, the change in their image will have broad political consequences.

The image that has been built by US foreign policymakers towards Israel so far is that Israel is a country in the Middle East that is surrounded by hostile Arab countries. Israel is positioned as a country that must continually defend itself from terrorist attacks and that's why the US is obliged to help Israel.

This image is seen in Obama's speech in the city of Sderot, Israel. At that time Obama said:

"If somebody was sending rockets into my house, where my two daughters sleep at night, I'm going to do everything in my power to stop that. I would expect the Israelis to do the same thing" (Kuzmarov 2019).

Coplin said there are three types of foreign decisions, namely foreign policy decisions that are general, administrative, and crisis. According to Coplin, "General foreign policy consists of a series of decisions expressed through policy statements and direct actions."

US general foreign policy towards Israel in the Obama era can be seen from his speech two days after being installed as president. In a speech at the US State Department on January 22, 2009, Obama said:

"Let me explain: America is committed to Israeli security. And we will always support Israel's right to defend itself in the face of real threats. Over the years, Hamas has launched thousands of rockets at innocent Israelis. No democracy can accept this kind of danger for its people, neither the international community nor the Palestinian people themselves, whose interests have been neglected 
due to acts of terror. As a party that truly wants peace, the Quartet (US, Russia, European Union, UN) has stressed that Hamas must fulfill these clear conditions: recognize the right of Israel's existence, stop violence, and abide by agreements (between Israel-PLO / Palestinian Authority ) that were created in the past."

Furthermore, in his speech in Cairo on 4 June 2009, Barack Obama said that Hamas does indeed have the support of some Palestinians, but they must also recognize that they have the responsibility to play a role in fulfilling the aspirations of the Palestinian people. Hamas must stop the violence, recognize past agreements, and recognize Israel's right to exist (Kuzmarov 2019).

On the same occasion, Obama was seen trying to be assertive towards Israel. However, he still preceded it with a sentence that confirmed the image that had been built so far, America's strong bonds with Israel are well-known. This bond is unbreakable.

Then Obama also said that at the same time, Israel must recognize that just as Israel's right to exist cannot be denied, Palestine's right to existence cannot be denied. The United States does not accept the legitimacy of Israeli settlement construction. Development (settlements) violates agreements and ignores efforts to achieve peace. It is time to stop the settlement.

However, as Gideon Levy writes after Israeli leaders were wary of waiting for the follow-up to Obama's speech, they have now relaxed and ensured that there is nothing to fear from Obama. Israeli leaders are now boldly issuing statements rejecting all proposals to stop the construction of settlements and even reject the establishment of a Palestinian state. In the face of Israeli dissent, Obama continued to submit a budget of 2.77 billion dollars for military assistance to Israel in 2010 (Sulaeman, 2009). 


\section{REVIEWING AL-QAEDA'S INFILTRATION}

US-Israeli relations are described by experts in various ways. Petras $(2008,51)$ writes that politicians consider Israel to be the most reliable US ally in the Middle East, if not worldwide. Others claim that Israel is a strategic ally. Still others say Israel and the US share the same democratic values in the fight against terrorism. On the left-wing, critics declare Israel as a tool of US imperialism, to undermine Arab nationalism, and as a bulwark against Islamic fundamentalist terrorism. Very little shows the "excessive influence" that the Israeli government has had on US government policy through strong Jewish lobbies, media people, and financial and government circles.

America also practices the politics of aggression. After 9/11, America attacked Afghanistan because it was accused of being "home" to Osama bin Laden who was called the mastermind of 9/11. After destroying Afghanistan, the US also attacked Iraq on the grounds that it had Weapons of Mass Destruction (WMD) on March 21, 2003. WMD is a weapon that can kill large numbers of people or cause great damage to man-made structures, natural structures, or the biosphere in general.

President Bush completely ignores criticism and objections from various anti-war countries. Only three weeks after the US aggression, the Iraqi state was completely under the occupation of US troops. The September 2002 CBS News broadcast showed that the plan to attack Iraq had been planned by Defense Minister Donald Rumsfeld, who during the 9/11 hours immediately phoned a number of his aides to look for various ways so that the 9/11 attacks appeared to be Iraqi (Mahajan 2005, 96).

Sihbudi (2007, 145-46) writes about America's new footing after successfully conquering Iraq as follows:

"By controlling Iraq, the US also gained a new foothold in the Persian Gulf region, because after the Islamic Revolution in Iran (1979), the US lost its main base in this region. Bush and his accomplices put Iraqi defectors to power in Baghdad to replace Saddam Hussein's regime, 
although the strength of opposition groups in Iraq - outside the Kurds and Shiite Muslims - is not so strong."

Another goal that America wants to find by invading Iraq is to find the mastermind of 9/11. Because it failed in Afghanistan, then the scenario to suppress Iraq and hunt down Bin Laden was carried out. However, after Iraq was destroyed, Bin Laden was also not found. This is a clear fact of how America is aggressive in its enemies.

One of the acts of terrorism carried out by Al-Qaeda is caused by foreign policy. Aid for American assistance to Israel has resulted in prolonged misery for Palestinians. Mearsheimer and Walt $(2007,24)$ say, "there is no denying that Al-Qaeda leader Osama bin Laden is motivated by Israel's presence in Jerusalem and the plight of the Palestinian people". Meanwhile, Esposito $(2002,1998)$ sees that widespread anger is not only caused by blind anti-American sentiment, but also because of American foreign policy in Arab and Muslim societies. Esposito writes that "many who see US support for self-determination, democratization, and human rights, are not honest in their foreign policy views". Muslims consider that issues like Palestine are one of the most important issues in the world. Foreign policy is a reflection of the national interest of the nation itself. In a poll conducted by Zogby International on American Muslims (November-December 2001), 84 percent believed that the US should support a Palestinian state and 70 percent believed that America should reduce its financial support for Israel.

The level of political disappointment or dissatisfaction with Western domination and intervention in the Muslim world has increased the desire of Muslims to uphold Shari'a and form resistance organizations such as Al-Qaeda. Here, there is a fact that political policies that are not pro-Muslim cause Muslims to build a movement (one of them with a movement that commits acts of terrorism) to uphold Islamic honor. 


\section{REVIEWING AL-QAEDA'S INFILTRATION}

John Esposito (2008) noted that the 1990-1991 Gulf War had transformed Osama bin Laden's Al-Qaeda from a support group in the Afghanistan-Soviet war into a global militant network. While condemning the presence of non-Muslim forces in the land of Islam, Saudi Arabia, as a sacred violation, Osama bin Laden views the Western military presence, especially America, in Saudi Arabia as "occupation" which will lead to greater dependence on Gulf states. More than a decade later, the US-led invasion and occupation of Iraq and Israeli attacks on Gaza and Lebanon were exploited by terrorists to recruit "liberation fighters" to expel the West and protect Muslims.

Bin Laden writes that the Islamic world has now spread in it a great ugliness, namely that the rulers are calling on humans to Jahannam. This is evident in the rulers of various countries - the rulers of the Arab world and the Islamic world - in their information media, and in the various destructive media that they have. They call on people through destructive thinking and build positive legislation and legislation on products of reason. They call on people (not morning nor evening), to the doors of Jahannam, while no one denies it ...” (Craig 2006).

The inclusion of US troops into the holy land, according to Bin Laden is also an "occupation" of Islam. Laden uses the foundation of a hadith which states that the people who are most angry with Allah are those who do evil in the land of haram. Another hadith "Get rid of the polytheists from the Arabian Peninsula", became the cornerstone of Al-Qaeda's movement to urge America to withdraw from Arab lands. The limit of the Arabian Peninsula according to Bakar Abu Zaid: to the west is the Sea of Qulzum (Red Sea); to the south is the Arabian Sea (Yemen Sea) and east of Basra Bay (Arabian Gulf). As-Syu'aibi said that Jews, Christians, and polytheists were not allowed to stay in the Arabian Peninsula for a while or forever. However, some other scholars allowed it for three days in an emergency. 
The al-Qaeda leadership's strong stance that decided to emigrate and form a new global network is to uphold Islam. Islam is currently in a fragmented situation after the destruction of the Ottoman Khilafah in 1924. Al-Qaeda sees that the biggest enemy of Islam today is America (including Israel) whose policies discriminate against Islam. The Front formed in 1998 to fight America and Jews is a movement for all Muslims to join against enemies who are unjust towards Islam.

Al-Qaeda's extremism which opposes US foreign policy is a logical consequence of policy. Because US foreign policy is "double standard", on the one hand, it supports democracy but on the other hand, it suppresses the Islamic movement that won in the Election, thus resulting in resistance from the Al-Qaeda movement. As the Afghan War alumni are spread, there will always be opposition to US foreign policy. Therefore, Esposito (2002) proposed that the reformulation of US foreign policy would be necessary to limit and effectively curb global terrorism.

In the context of the foreign policy above, Marsheimer and Walt (2007) analyze that two things provoke the rise of Islamic extremists such as Al-Qaeda to commit acts of terror. Both of these are closely related to American hegemonic and aggressive foreign policy.

Daulay (2009, 89-90) writes: First, American alignments with Israel by providing excessive economic, military and diplomatic assistance. It not only caused jealousy, but also a feeling of being threatened among Gulf countries and non-state groups, such as Al-Qaeda. Israel's economic and geostrategic position for America is not comparable to American assistance to Israel. The main reason for giving aid is because of moral reasons, that for thousands of years Israel suffered in various countries that made it scattered (diaspora) so it needs to be supported in the struggle to get its own country. 


\section{REVIEWING AL-QAEDA'S INFILTRATION}

Second, the American military presence in Iraq and other Gulf countries is considered by Gulf countries and militia groups such as Hamas and Hezbollah (also Al-Qaeda) as occupation and insult to Islamic countries. This opinion is in line with comments from Feisal Abdul Rauf who said that acts of fundamentalist Islamic terror arose when they (the Gulf States) felt that America and its allies were robbing the assets of the Middle Eastern nation, especially the abundant energy resources.

This hegemonic and aggressive US foreign policy factor has fallen into shape in the character of the Al Qaeda movement. The saying goes "there is no smoke if there is no fire". In the context of the American war against Al-Qaeda, the "smoke" of the Al-Qaeda movement which terrorizes US interests in various places is because there is a "fire" that is ignited by America itself.

According to Chomsky (2003), there is one way to stop terrorism in the world today, "stop participating with America". Chomsky criticized countries that received help from America and participated in the war on terror campaigned by America. If countries stop in coalition with America, according to the professor at MIT, "will reduce the number of acts of terrorism in this world by a large quantity.”

\section{The Vision of Islamic Unity}

The Khilafah Islamiyah collapsed in 1924. Previously, the movement to destroy the institution of the Khilafah took place through the Arab revolution in Hijaz to fight the Ottoman Turks. The Sykes Picot (1916) agreement between Britain and France to divide post-Ottoman rule was that scenario. In the Balfour Agreement, a year after Sykes Picot, namely 1917, Britain as the dominant ruler in the Middle East gave Palestinian land to the Zionists. European Politics over the Ottomans made Islamic rule hereditary collapse (Tharsyah 2008). 
The negative effect of the collapse of the Khilafah is that divisions occur among the Muslim nation. In the end, nationalism originating from the West is practiced in Muslim countries. According to Bin Laden, currently, Muslims do not have a country that runs Islamic sharia. Since the collapse of the Khilafah, he said, "The Crusaders tried hard not to let Islamic honest Muslims establish a state".

Bin Laden argues that the Afghan jihad fieldsman is an excellent opportunity to uphold the Islamic state (state) because it is far from fanaticism of the state and tribe. The history of the success of the Islamic state can be seen from justice in the time of the Prophet when he was the head of state. In the age of the four caliphs, justice and Islamic law proceeded because the leaders were among the best cadres first in Islam. Including, at the time of the caliph Umar bin Abdul Aziz who was very difficult to find people who were willing to accept zakat, because the community was prosperous.

Before the movement Al-Qaeda was formed, the Mujahideen of Afghanistan have a shared vision to carry out Islamic sharia with the establishment of an Islamic state. With this idea, it means that everything contrary to the conception of Islam, needs to be opposed and there is no wala' (obedience), including the ideology, empire or ruling regime.

Nasir Abas $(2007,71-72)$ explains the vision of the struggle of seven mujahidin groups for the establishment of an Islamic state. That is, regional unity of Islam, even internationally, needs to be reawakened especially since the Khilafah Islamiyah which covered all Muslim countries had ended in 1924. He writes that since the beginning of the Afghanistan Mujāhidīn movement in Afghanistan, these seven groups have fought against the same enemy, the Russian army and the communist government of $\mathrm{Ka}$ bul and with the sole purpose of defending Islam and establishing Islamic sharia in an Islamic state. 


\section{REVIEWING AL-QAEDA'S INFILTRATION}

The idea to establish an Islamic state, including an important point in the Al-Qaeda movement. Therefore, since the Al-Qaeda movement was established in Afghanistan, it is not enough just to join Muslims in the region. The expansion and spread of the movement are needed to unite the potential of Muslims for the establishment of the Islamic State and the Islamic caliphate.

The spread of the Al-Qaeda movement outside Afghanistan, including to Indonesia, also has the intention to expand the area of the battle as a derivative of a sense of ukhuwah Islamiyah that is not bound by place and time. Imam Samudra $(2004,161)$ one of the death row convicts of the Bali Bombing, mentions the action together with his friends as follows:

"The Bali Bomb Jihad is a form of ukhuwah Islamiyah. As an expression; one body, like a building, bitter bitter, miserable suffering. What is experienced by Muslims in the land of Palestine, Afghanistan, Kashmir, Iraq, and others, is enough to touch and vibrate the conscience of all Muslims. Signs of pain are also spreading in the believers in any hemisphere, from any nation, and any language. During the time he was a believer, as long as he will also feel pain for the pain of his brethren."

After the Cold War, America became a victorious country and there were no more comparable enemies. World conditions become bipolar, only one pole. Samuel Huntington mentioned that Islam is a threat to the West. In fact, bombs aimed at American interests indicate that there is a problem between Islam and the West. The problem is related to the ideological struggle, between Islam or capitalists.

The expansion of the battle area was intended by Al-Qaeda as one of the strategies to unite the Muslims scattered by the state. With a common issue to uphold the Islamic state, then it is hoped by Al-Qaeda that Muslims are striving to achieve that state. And to get to the establishment of the Daulah, the resis- 
tance to the American superpower needs to be faced as a clash between the forces of al-haq (truth) and al-bathil (sleaze).

Hijazi (2009) writes Al-Qaeda's thoughts on why it should expand the battle area as follows:

"... this is the most urgent thing to describe because it means making the countries in the Islamic world, both united and separate, an actual battle area with all the catastrophic effects it will cause. It also means the elimination of the view which states that "Egypt, Palestine, or Afghanistan first ..." from the minds of jihadi movements, replacing them with the idea of "the area of battle first". This kind of thinking was brought by movements in Palestine to involve Arab countries in the war against Israel."

With the expansion of this battle zone, Americans will not feel safe because Al-Qaeda cells are scattered in many places. The cells can attack at any time, and the leader is unknown where they are. Al-Qaeda's movement, which spread to many countries, aims to unite Muslims on one front against America and Jews.

The development of networks originating from across continents makes this movement has an advantage in launching local attacks that harass the security forces and espionage. Besides, it is useful to make Western societies uncomfortable, anxious, there is a "great fear" (fear of a large) because of the unknown spy. The Bin Laden Fatwa in 1998, was a movement to unite Muslims. Laden felt it was important to unite the Muslims because the existing movements did not succeed in uniting against American hegemony.

Hamka $(2005$, 654) writes about the duty of Muslims to continue the Islamic Khilafah, as follows:

"With the end of the Ottoman Empire from the world, it is up to faith and Islam into the hearts of each of its adherents. And after the Ottoman Empire was exhausted, 


\section{REVIEWING AL-QAEDA'S INFILTRATION}

the First World War was overtaken by the Second World War. The Turks themselves, who used to hold the Ottoman Empire and use the title of Khalifah, still stand as a nation ... But in addition to Turkey within 30 years, there have also been other Islamic countries. Both Arab countries, or Pakistan and Iran or Indonesia. Everything proves that the task of upholding Islam as a religion is not stopped because of the fall of the Ottoman Empire. But that task has been continued by the newly born Muslim nations."

Bin Laden's idea to establish the Islamic Khilafah had the aim of establishing Islam as a blessing for the universe. Confidence in that grace requires this movement to face the obstacles that appear before the eyes. Therefore, the resistance movement against America is always guarded by escalating fluctuations.

As described in the previous section, that Al-Qaeda has a long-term goal to shape the Islamic state. With this idea, the spread of Al-Qaeda's ideas and cells reached Indonesia. From 2013 until the beginning of 2016 was the period of Al-Qaeda's plan to proclaim the Khilafah Islamiyah state with the consideration of the weakening of enemies throughout the world, and the emergence of new forces with no significant contradictions among Muslims.

\section{Post-Reform Freedom Climate in Indonesia}

The 1998 reforms forced Suharto to resign from his position. With the fall of Soeharto, the New Order was declared to have been replaced by a more recent order called reform. In the reform era, the democratic climate is more open. In the political field, there is liberalization. The increase in parties participating in the General Election is an indication of the euphoria of the Indonesian people over reform. This includes freedom of speech and assembly. 
A free spirit of speech in a democracy is possible as long as it does not violate any applicable law. This is exploited by many movements, including Al-Qaeda to do activities in Indonesia. In many ways, propaganda in Indonesia developed after the reform. This brings its advantages to the da'wah movement.

Movement Al-Qaeda, which was founded by Bin Laden, originally came from Maktab al-Khidmat and Bait al-Anshar as a database and training for mujahideen from all countries before entering the Afghan war. The mujahideen, including those from Indonesia. When the Afghan War was over, the mujahideen returned to their respective countries, they saw the fact that the leader was far from the value of Islam.

With the reformation in the country after the fall of the New Order in May 1998, the movement Al-Qaeda became spread to Indonesia. This becomes necessary because at this time the development of the era is so fast, and the flow of information passing by does not know geographical. Arrahmah.com site for example, in its news, spread a lot of information about the Al-Qaeda movement from around the world. From the news, then the head of the site is referred to as one of the Al-Qaeda networks in Indonesia, including in connection with the bombing of the Ritz-Carlton Hotel and JW Marriot.

The era of openness makes recitations unrestricted. During the New Order era, if a group gathered and had indications to conflict with Pancasila, then the movement could be directly arrested by the authorities. However, during the reform period, free study was carried out everywhere, from small blades to television that had a greater range of influence.

Freedom of making Al-Qaeda is also more flexible in Indonesia. After the reforms, the level of bombings was more intense than in the Suharto New Order era. The Bali bombing and several embassies and hotels showed more significance in the reform 


\section{REVIEWING AL-QAEDA'S INFILTRATION}

era than in the New Order era. This proves that reforms become fertile ground for the growth of movements such as Al-Qaeda.

From this fact, it can be seen that the reform era also influenced the spread of movements Al-Qaeda in Indonesia. The resistance front formed by Bin Laden in 1998 received enough response from fellow Afghan alumni in Indonesia. The 1998 global front seemed to be a momentum for Afghan alumni activists in Indonesia to join at least fikrah (thought) in common.

According to Barack Obama, groups that are affiliated or inspired by Al-Qaeda operates throughout the world. After 9/11, the threat to America increased more than before the fateful event. The people recruited by Al-Qaeda came from various parts of Asia and Africa, the Middle East and Europe (Olive 2008). And reform is the right momentum for Al-Qaeda's nursery to spread its network.

\section{Al-Qaeda Infiltration and Its Influence in Indonesia}

At least, to see the prospect of the Al-Qaeda movement, there are two things that we need to pay attention to, namely in terms of thinking and from the organizational movement. The thinking of the Al-Qaeda movement is to uphold the Islamic caliphate. In its movement, Al-Qaeda in Indonesia continues to take fatwas from clerics in Afghanistan, Iraq, and Pakistan.

From an ideological point of view, as long as there is still American imperial influence in Indonesia, the movement Al-Qaeda will still exist. America in addition to exploiting the wealth of Indonesia (in a spread MNC), also spreads its culture and lifestyle that is contrary to the beliefs of Al-Qaeda members to uphold Islam.

Sayyid Qutb (1991) emphasizes that Islam is a system, a living system, the human life that can be practiced in all aspects of life. This system embraces the concept of trust (i'tiqād) which can explain the nature of the existence of the universe and can 
determine the position of human beings in this world and determine the living conditions of human beings .. among these systems are moral systems, including their source, the principles that become the pillars, and the source of their power; political system, including its forms and characteristics; the community system, the economic system, its philosophy, and structure as well as the international system, with all interwoven links.

Ideologically, as long as there is persecution by America or its allies, this movement will still exist. Included in this case is the attitude of the Indonesian government on the issue of Islamic sharia. A few years ago there was much buzz in Indonesia about the idea of establishing Islamic sharia. In several places in the regencies/cities, regional regulations with Islamic sharia principles were held, as was done by the Government of the Regency of Bulukumba under the leadership of Patabai Pabokori. However, later the issue of Shari'ah became helpless because of the pressure put on by the US with the anti-terrorism movement which the perpetrators of the bombings in Indonesia are inseparable from the belief that the need for Islamic sharia in this country.

Whereas in terms of movement, Al-Qaeda in Indonesia does not appear openly or in the form of an underground organization (clandestine). Its existence exists but in the form of a Formless Organization for the security of its organization. This is useful as an existence that Al-Qaeda already exists in the region, such as the declaration that occurred in Al-Qaeda in northern African countries.

In his article titled "Who are the terrorists in Indonesia?", Sidney Jones (2002, see 2018), looks at the incident with three theories summarized below:

First, the American embassy issued a warning to its citizens to avoid public places in Indonesia twelve hours before the explosion. The CIA chose a place frequented by Americans and 


\section{REVIEWING AL-QAEDA'S INFILTRATION}

supplied materials for bombs. From that incident, Al-Qaeda and Islamic radicals were accused. This was done as an effort to win support for the war on Iraq and offered to assist in the investigation as a way to infiltrate American troops into Indonesia so that America could finally build a new footing in Southeast Asia.

The second theory, according to Jones, is common among Indonesians living in conflict areas. This theory shows that the Indonesian National Army (TNI) is the culprit. The TNI has tried since the fall of Soeharto to reaffirm its role in provoking the government with conflict and then came to establish order. Proponents of this theory state that in reality the army supported the formation of Laskar Jihad (LJ), or the involvement of special forces troops in the death of Papuan independence leader, Theys Eluay. The struggle between the army and police to control internal security has become increasingly bitter and violent in the past year, and on the scale of the explosion, Bali can support the army. Aceh and Papua activists believe that new anti-terror policies will be used by these circles.

The third theory is "Al-Qaeda theory ", but has few supporters. This theory sees that the relentless US pressure on the Indonesian government to act on Indonesian citizens associated with the Jama'ah Islamiyah black network has convinced many Indonesians that their security services are forced to accept US versions of events. Umar al-Faruq's information - a man who was arrested in West Java in June 2002 - published in Time magazine, proves that there are plans by the Al-Qaeda group to kill President Megawati (Tran 2002).

Because of the movement, Al-Qaeda is not an official organizational form, so the influence of this movement can be weakened along with the death of the figures. Azahari's death, Noordin M Top, was one of the losses for the Al-Qaeda network in Southeast Asia or Indonesia. However, that does not 
mean that the network will just die. As for the movement, there are opportunities to form this movement formally. This underground movement still exists with the vision it carries, which is anti-Western and upholding Islam. As long as this vision still exists, the name of the existence of the movement will remain.

The development of the internet world, helping the movement Al-Qaeda to always exist. Video postings of his actions in many places, or those released in global jihadist forums in cyberspace, make Al-Qaeda not easily eroded. Some jihadist forums that exist are al-Ikhlas, al-Hisbah (in Arabic), and al-Firdaws English Forum. Among the members in this forum came from Islamic countries such as Egypt, Afghanistan, Iraq, Sudan, to Eritrea and Spain. Jihadmagz (2008, 143) writes, "Such forum sites do have the privilege of being able to unite all Muslims from all over the world in just seconds".

Internet is used by people Al-Qaeda to communicate with one another. Before being caught, Imam Samudra had prepared 13 reasons for him and his friends to carry out the Bali Bombing. These reasons will be published via the internet (Sunarko 2006, 49). From this fact it can be seen that the internet as a means for spreading ideas is used by the Bali Bombing network. The distribution of information in cyberspace is relatively safer than direct distribution of pamphlets distributed in the real world.

Among Arabs themselves, before technology evolved, there were those who assumed that technology was something foreign and dangerous to them. When the radio airs in a place in Arabia, there is from a group that considers the voice of the radio to be "the voice of the devil" (Interview of Lutfi A Tamimi, 6 October 2009). However, with the development of time, radio and the internet have become human needs.

Carl J Jensen writes about the use of the internet used by terrorist movements, as follows: 


\section{REVIEWING AL-QAEDA'S INFILTRATION}

"Maybe in the past 20 years, there has been no greater blessing for terrorist groups than the internet. As predicted by Toffler (1991) and others, our society has become an information society. We are socially and economically dependent on the internet. This dependence will no doubt increase as we enter the future. The development of technology is a double-edged sword, and the internet is no exception" (Permata 2006, 357).

According to Jensen, besides offering attractive targets, the internet also provides various other benefits for terrorists. The internet is becoming a great source of information today. In context Al-Qaeda in Indonesia, the movement (or which claims) to be Al-Qaeda also on behalf of Noordin M. Top also used a free site to spread the information.

Media as-Sahab is one of the media that is referred to as the official branch of the Al-Qaeda. Media which are published on this site are mostly in videos, audio and short statements related to military operations in Afghanistan against the United States, NATO is included in the pagan class. Jihadmagz writes, that if Osama bin Laden and Ayman al-Zawahiri want to talk to the people, they use the media as-Sahab (Jihadmagz 2008).

Death row inmate Bali Bomb, Imam Samudra also stressed the importance of the internet for activities against America. Samudra even invited to learn the science of hacking by mastering several programming languages such as Linux, Unix, Perl, Delphi, Pascal, and CGI (Common Gateway Interface). Samudra, an activist of Jamaah Islamiyah, wrote, "If only the infidels whose whole lives are ignorant can understand and master the science of hacking, then as Muslims we must choose the belief that we, God willing, will master the same thing ...” (Samudra 2004, 266).

Al-Qaeda is a formless organizational movement because its structure is not clearly visible. Therefore, the influence that 
Al-Qaeda has on the terrorist movement in Indonesia lies in its people and actions, in this case, Jamaah Islamiyah is its network for entering Southeast Asia. Those from Jamaah Islamiyah who was recruited by Al-Qaeda then after going through a series of doctrines finally carried out activities similar to Al-Qaeda's vision. This can be seen in the activities of the Bali Bombing (2002), the Kuningan Bomb, Marriot and Ritz-Carlton Jakarta (2009). For Al-Qaeda, the growing radicalization among Muslim Jamaah Islamiyah groups in Indonesia and Southeast Asia is the domino effect of the depravity of the social system of people who no longer heed moral and religious teachings. That is why Al-Qaeda believes that Islam can solve almost all the problems of society to become more Islamic; so that there is no imperialism, capitalism, Zionism, neoliberalism and moral damage and multidimensional crises in this modern era. Of course, if it spreads, there are still many reasons and problems that make the radicalization of Muslims happen and it becomes a social capital for Al-Qaeda, its networks, and supporters to build the power of terrorism in Indonesia. In Indonesia, the media that often spreads the ideas of Al-Qaeda's struggle along with its activities is Arrahmah Media Network (which manages the jihad information web, publishes books, VCDs, and Jihadmagz magazines) under the leadership of Muhammad Jibriel Abdul Rahman (Abu Jibriel's son). In the case of the JW Marriot and the Ritz-Carlton bombing,

It seems clear, as long as the internet is still a human need and spread in many places, then the movement Al-Qaeda continues to communicate with one another. Although Bin Laden is said to not use telecommunications facilities such as mobile phones or e-mail, his couriers or supporters use the internet to spread their influence.

Even not only in Indonesia, Al-Qaeda also built networks and power bases of Jamaah Islamiyah in Southern Mindanao, 


\section{REVIEWING AL-QAEDA'S INFILTRATION}

Philippines. Al-Qaeda's involvement in Southeast Asia includes the provision of funds and military training from several militant Islamic groups in Indonesia, Malaysia, and the Philippines and plans to deepen their influence in the Southeast Asian region, where around 210 million people are Muslims (Tim Peneliti Hubungan Internasional P31 DPR-RI 2002, 140). Included in the Al-Qaeda network are actors in the Moro Islamic Liberation Front movement, the Moro National Liberation Front and Abu Sayyaf guerrillas in the southern Philippines, all of which increasingly make Al-Qaeda's power in the southern Philippines more alarming and in turn encourage the United States to strengthen war action anti-terror in the Southeast Asian region.

\section{Conclusion}

Al-Qaeda successfully entered Indonesia through the Jamaah Islamiyah network and its cells in Indonesia. In Indonesia, Jamaah Islamiyah with the support of Al-Qaeda has carried out several bomb attacks in Jakarta and Bali. Among them the Bali Bombing (2002), Kuningan Bomb (2004), Marriot and Ritz-Carlton Jakarta (2009). Their alliance and network have succeeded in bringing them into the conflict areas of Poso and Ambon. In the Philippines, they blew up the Manila airport and blew up some churches and carried out various other terrorist attacks. In Malaysia, they launched various acts of terrorism in Kuala Lumpur, although they were not very effective.

In terms of movement, Al-Qaeda in Indonesia does not appear openly or in the form of underground organizations (clandestine). Its existence exists, but it is in the form of a Formless Organization. In Indonesia, due to the tight monitoring of intelligence and the National Police / TNI on this radical movement, Al-Qaeda chose the path of the Clandestine, as a formless organization, but continued to carry out acts of terror like people who went on a rampage. 


\section{Bibliography}

Abas, Nasir. 2007. Membongkar Jamaah Islamiyah: Pengakuan Mantan Anggota JI. Jakarta: Grafindo.

Chomsky, Noam. 2003. Power and Terror: Post-9/11 Talks and Interviews. New York: Seven Stories Press.

Craig, David. 2006. Osama Bin Laden's Personal Diary: 20032004. Indiana: iUniverse.

Daulay, Richard. 2009. Amerika VS Irak: Bahaya Politisasi Agama. Jakarta: Libri.

Dreyfuss, Robert. 2007. Devil's Game: How the United States Helped Unleash Fundamentalist Islam. Edited by Asyhabudin. Yogyakarta: SR-Ins Publishing.

Edwards, Beverley Milton, and Peter Hinchcliffe. 2004. Conflicts in the Middle East Since 1945. London: Routledge.

Esposito, John L. 2002. Unholy War: Terror in the Name of Islam. Oxford: Oxford University Press.

—. 2008. Saatnya Muslim Bicara. Bandung: Mizan.

Esposito, John L. 1998. Islam and Politic. New York: Syracuse University Press.

Hamka. 2005. Sejarah Umat Islam. Singapore: Pustaka Nasional.

Hijazi, Akram. 2009. Rihlah Fi Shamimi Aqli As-Salafiyah Al-Jihadiyah. Edited by Abas Sungkar. Klaten: Kafayeh.

Hoffman, Bruce. 2006. Inside Terrorism: Revised and Expanded Edition. New York: Columbia University Press.

Huntington, Samuel P. 2007. The Clash of Civilizations and the Remaking of World Order. New York: Simon and Schuster. Jihadmagz. 2008. “Edition III,” 2008.

Jones, Sidney. 2002. "Who Are the Terrorists in Indonesia?" The 


\section{REVIEWING AL-QAEDA'S INFILTRATION}

Guardian, 2002.

- 2018. "How ISIS Has Changed Terrorism in Indonesia." The New York Times, 2018.

Kean, Thomas Howard. 2004. "9/11 Commission Report - Final Report of the National Commission on Terrorist Attacks Upon the United States." Washington D.C.

Kuzmarov, Jeremy. 2019. Obama's Unending Wars: Fronting the Foreign Policy of the Permanent Warfare State. Atlanta: Clarity Press.

Mahajan, Rahul. 2005. Full Spectrum Dominance: U.S. Power in Iraq and Beyond. Edited by Anom. Jakarta: Mizan.

Mearsheimer, John, and Sthepen Walt. 2007. The Israel Lobby and US Foreign Policy. Edited by Raja Ari Hidayat. Jakarta: Kalam Indonesia.

Olive, David. 2008. An American Story: The Speeches of Barack Obama: A Primer. Toronto: ECW Press.

Permata, Ahmad Norma, ed. 2006. Agama Dan Terorisme. Surakarta: Muhammadiyah University Press.

Petras, James. 2008. The Power of Israel in USA. Jakarta: Zahra.

Qutb, Sayyid. 1991. Al-Mustaqbal Li Hadza Al-Din. Riyadh: International Islamic Publishing House.

Samudra, Imam. 2004. Aku Melawan Teroris. Solo: Jazeera.

Sihbudi, Riza. 2007. Menyandera Timur Tengah. Jakarta: Mizan.

Sulaeman, Dina Y. 2010. "Analisis Kebijakan Luar Negeri AS Terhadap Israel Pada Era Obama.” The Global Review. 2010. http://theglobal-review.com/lama/content_detail. php?lang=id\&id=1251\&type $=4$.

Sunarko, A Dwi Hendro. 2006. Ideologi Teroris Indonesia. Jakarta: Pensil-324. 
Tharsyah, Adnan. 2008. Islam Kok Dilawan. Solo: Jazeera.

Tim Peneliti Hubungan Internasional P31 DPR-RI. 2002. Terorisme Dan Tata Dunia Baru. Edited by Poltak Partogi Nainggolan. Jakarta: DPR RI.

Toffler, Alvin. 1991. Powershift: Knowledge, Wealth, and Violence at the Edge of the 21st Century. New York: Bantam.

Tran, Mark. 2002. “Megawati's Dangerous Balancing Act.” The Guardian, 2002.

Wright, Lawrence. 2007. The Looming Tower: Al-Qaeda and the Road to 9/11. New York: Vintage Books.

Zainuddin, AR. 2004. Pemikiran Politik Islam: Islam, Timur Tengah Dan Benturan Peradaban. Jakarta: Pensil-324. 